\title{
Evaluating the effectiveness of franchise in tourism
}

\author{
Elena Ganebnykh ${ }^{1, *}$, Olga Fokina $^{1}$, Tatyana Burtseva ${ }^{1}$, and Ilia Yanov $^{2}$ \\ ${ }^{1}$ Vyatka State University, Russia, 610000, Kirov, Moskovskaya str., 36 \\ ${ }^{2}$ Moscow State University of Civil Engineering, Yaroslavskoe shosse, 26, Moscow, 129337, Russia
}

\begin{abstract}
Russian tourism industry is going through hard time. Devaluation of Russian ruble and bankruptcy of several major tour operators caused customers mistrust. Market players are forced to unite, consolidate. One of the most effective ways to withstand in this hard time is franchising. But how a beginner of touristic retail market can pick the right one? How a tour operator can build an effective franchise and attract more professional agents in own network? Developed model is based on mathematic analysis of the most important factors - component parts of franchise. This model as well as the general technique allows by simple calculation evaluate the effectiveness of franchise. The modern condition of Russian tourism market is next: strengthening of the tour operator market; those who survived gained the reputation, others are out of game; a clearer division of Agency market into niches; the change of relations scheme between market players. Small players are forced to unite, consolidate; increasing the service quality in attempt to keep customers.
\end{abstract}

\section{Introduction}

Devaluation of Russian ruble within 2014 near twice, led to the crisis in tourism industry. In autumn 2014 tour operators in Russia reported about 30-50\% demand reduction (Russian Association of Tour Operators). The bankruptcy of several major tour operators in local market caused customers mistrust. By information of Russian Federal Agency for Tourism the quantity of tour operators reduced $30 \%$ in 2014 [1-6]. The prognosis of executive director of Russian Association of Tour Operators [3,7] is even greater reduction in the number of tour operators in Russian market over another 30\% in 2015.

The modern condition of Russian tourism market is next:

1. Strengthening of the tour operator market. Those who survived gained the reputation, others are out of game.

2. A clearer division of Agency market into niches.

3. The change of relations scheme between market players. Small players are forced to unite, consolidate.

4. Increasing the service quality in attempt to keep customers.

\footnotetext{
* Corresponding author: ganebnykh@mail.ru
} 


\section{Methods}

We have developed the technique that takes into account the interests of both parties. The structure of developed technique is displayed on the Figure 1.

Stage 1 - Collection and analysis of effectiveness factors. Franchising relationship touches different parties: franchiser seeks to maximize franchisee's gross revenue, because the size of royalty depends on it; franchisee seeks to maximize margin, because his income is based on it. Different goal settings shape different view to the franchising relations effectiveness.

We found out 25 factors that affect franchising relations (Table1):

Stage 2 - Expert survey among franchisors (tour operators) and franchisee (tour agents) to find out the key factors. At the March 2015 in annual Russian touristic exhibitions MITT-2015 we have run the expert survey. At the days of professional visitors 186 responders evaluated by 10-point scale the importance of each factor ( 1 - the least important factor, 10 - the most important factor). We divided forms of franchisers (potential franchisers) and franchisee (potential franchisee) supposing their view can be different. We have assumed another additional factors and gave an ability to add them over the list, but none of surveyed used this option. So we can conclude that offered 25 positions are fully reflecting the scope of factors.

Stage 3 - Factorial analysis. Factorial analysis is used to reduce the quantity of factors, but to keep the maximum information [2,8-10]. First of all we built the correlation matrix and found out many correlations between factors. This means that there are interdependent factors and factorial analysis can be applied.

The most important factors have percentage over value $4.0 \%$ (100\% / 25 parameters) and they are 3 in total. The model of factorial analysis (franchisers) is displayed.

By the same way we made the factorial analysis of data from franchisee.

Stage 4 - Finding the community of franchiser's and franchisee's factors. In generally we can say that both groups have similar view to the franchising relations. The difference is that tour operators have more care to the business reputation (legal suits, franchisee's reviews) while tour agents pays attention for investments in franchise. Interesting fact: franchisers are mistaken in their belief that exclusive rights have big weight in decision to buy franchise, because franchisee gave very low rate to this factor.

So we picked up highlighted factors, evaluated communities and found out correlation coefficients. High community rates indicate the most important factors for both groups of responders.

Stage 5 - Interpretation of results. Factor 1 group reflects the experience of franchising relations (quantity of franchisee, quantity of outlets in network, quantity of franchiser's staff who takes care of franchisee, finance results of franchiser's operations, audit). Factor 2 indicates franchise features (industry sector, duration of the brand in market after franchise, franchise package (equipment, techniques, know-how, software). Factor 3 unites financial parameters of franchise (initial franchise fee and royalty). Stage 6 - Evaluate the weight coefficients of factors using Analytic Hierarchy Process [5].

\section{Results}

Using the AHP involves the mathematical synthesis of numerous judgments about the decision problem at hand. AHP method means establishing priorities among the elements of the hierarchy by making a series of judgments based on pairwise comparisons of the elements. For example, when comparing potential purchase of touristic franchise, the entrepreneur might prefer bigger quantity of franchisee in network over the quantity of franchiser's staff that takes care of franchisee. The pairwise matrix is displayed in table 6 . 
Stage 7 - Development of Evaluation Model.

Based on factor's weights from table 6 we can develop the Evaluation Model for effectiveness of franchising relations in tourism industry.

\section{Discussion}

One of the most effective ways to withstand in this hard time is franchising. The positive experience of successful business multiplication via development of franchising networks finally took its place in the Russian economy and gained tremendous growth within last 10 years. But still the most common researches in franchising economy are related to adoption of European or American experience.

Franchiser as well as franchisee realize the effectiveness of collaboration after a while, when money are invested, time and resources and wasted and obligations are archived. The balanced assessment of franchising relations effectiveness can be achieved by franchiser after 5 years of work with a number of franchisee. Franchisee himself usually has 1, rare 23 franchisers, thus has even worse situation.

There are outsourcing companies that can assist with professional choice or creation of franchise in the USA and Europe. As soon as this market niche in Russia is empty, with the financial aid of Russian Foundation for Humanities (science project 15-12-43012), we have developed the technique that gives an ability to make the right choice of franchise for beginners and evaluate the effectiveness of franchising relation for those who already in.

Foreign evaluation methods can be classified as next:

1. Methods based on territorial approach (extensive way). The key indicator is vacant territory. Franchiser tries to promote his brand in new regions: quantitative growth. Franchisee looks for a new franchise for his location: less competition.

2. Methods based on marketing approach. The key indicator is a market's potential. Here both, a franchiser, and a franchisee are looking for abilities of market to consolidate logistic, advertising, marketing researches, and other important expenses.

3. Methods based on the proximity of the resource bases. These methods are usually used in manufacturing franchising.

4. Methods of add-on. New territories are studied in the context of preparation of ground by one franchise for the further promotion of associated businesses.

5. Finance approach. The key indicators are financial purchasing capacity of intended customer base.

The above methods can be useful for franchiser, but don't make any sense for franchisee. All evaluation methods that valid for franchisee are based on allocation of different criteria, which can classify franchises. British Franchising Association groups these criteria in next way [1]:

1. Success of franchiser's own business. Than more experience of business before franchise issue, than higher probability of franchisee's success.

2. Finance factors. Than higher profitability and lower financial expenses, that better franchise. So a franchisee has to attention for initial franchise fee, royalty, ingredients of franchise in context of initial fees, projected profitability.

3. Business features. Simplifying business features in franchising: brand franchise requires a franchisee to purchase minimum quantities of goods; service franchising requires a franchisee to follow the technologies.

4. The level of involvement of franchiser into work franchisee's work. Here must be considered technical support, trainings, step-by-step manuals done by franchiser after the sale of franchise.

5. Exclusive rights. Franchisee has to attention to the question of market limitations, subfranchising rights, liabilities in cases of infringement. 
Lots of evaluation methods and approaches unite one general factor - these methods cannot be effective for both sides of franchising relations at the same time.

\section{Conclusion}

Russian tourism industry is going through hard time. Annually big quantity of touristic retail agencies are closing and even more are opening. It is reflecting the low level of entrepreneurial proficiency. Simple method can help for potential touristic agents to make the right choice for their future business.

Government affords different kinds of support for small business, including financial aids for franchise buyers, thinking any franchise guaranties success. Developed model as well as general technique allows calculating and picking the effective ones and rejecting fraud offers.

\section{Acknowledgement}

Financial aid of Russian Foundation for Humanities (science project 15-12-43012).

\section{References}

1. K. Naresh, Malhotra Marketing research: An Applied Orientation (Pearson Education, 2009)

2. T.L. Saaty, Fundamentals of Decision Making; the Analytic Hierarchy Process, (Ellsworth Avenue, Pittsburgh, PA 15213, 2006)

3. A. Mottaeva, MATEC 73, 07020 (2016)

4. A.B. Mottaeva, A. Zheltenkov, I. Stukanova, S. Ryabichenko, S. Zhuk, MATEC 73, 07026 (2016)

5. An.B. Mottaeva, As.B. Mottaeva, Int. Journal of Applied Engineering Research 1, 1023 (2015)

6. An.B. Mottaeva, As.B. Mottaeva, Int. Journal of Applied Engineering Research 1, 11 9 (2016)

7. E. Stein, N. Taskaeva, E. Chibisova, Procedia Engineering 165, 1410-1416 (2016)

8. T. Miroshnikova, N. Taskaeva, MATEC 73, 123284 (2016)

9. A. Pimenova, S. Kuzmina, N. Morozova, A. Mottaeva, MATEC 73, 07018 (2016)

10. L.V. Nikolova, D.G. Rodionov, A.B. Mottaeva, Int. Journal of Economics and Financial Issues 6(S3), 1-7 (2016)

11. A.I. Shlafman, Mikroehkonomika 3, 32-38 (2013) 